\title{
Clinical Approach to Mast Cell Activation Syndrome: A Practical Overview
}

\author{
Matito $\mathrm{A}^{1}$, Escribese $\mathrm{MM}^{2}$, Longo $\mathrm{N}^{3}$, Mayorga $\mathrm{C}^{4}$, Luengo-Sánchez $\mathrm{O}^{5}$, Pérez-Gordo $\mathrm{M}^{6}$, Matheu $\mathrm{V}^{7}$, \\ Labrador-Horrillo $\mathrm{M}^{5}$, Pascal $\mathrm{M}^{8}$, Seoane-Reula $\mathrm{ME}^{9}$, on behalf of the Comité de Inmunología \\ de la Sociedad Española de Alergología e Inmunología Clínica (SEAIC)
}

\author{
'Instituto de Estudios de Mastocitosis de Castilla La Mancha (CLMast), Hospital Virgen del Valle, Toledo, Spain \\ ${ }^{2}$ Department of Basic Medical Sciences, Faculty of Medicine, San Pablo CEU University, Madrid, Spain \\ ${ }^{3}$ Allergy Department, Hospital Universitario de Araba, Osakidetza, Vitoria, Spain \\ ${ }^{4}$ Allergy Research Group, Hospital Regional Universitario de Málaga, Instituto de Investigación Biomédica de Málaga-IBIMA, ARADyAL, Málaga, Spain \\ ${ }^{5}$ Allergy Department, Vall d'Hebron Hospital Universitari, Vall d'Hebron Institut de Recerca (VHIR), Universitat Autònoma de Barcelona (UAB), \\ ARADyAL research network, Instituto de Salud Carlos III (ISCIII), Barcelona, Spain \\ ${ }^{6}$ Basic Medical Science Department, Faculty of Medicine, CEU San Pablo University, ARADyAL, Madrid, Spain \\ 'IDP and Allergy Department, Hospital Universitario de Canarias, Tenerife, Spain \\ ${ }^{8}$ Immunology Department, CDB, Hospital Clínic de Barcelona; IDIBAPS, Universitat de Barcelona; ARADyAL research network, Instituto de Salud \\ Carlos III (ISCIII), Barcelona, Spain \\ ${ }^{9}$ Pediatric Allergy and Immunology Unit, Hospital General Universitario Gregorio Marañón, Madrid, Spain
}

J Investig Allergol Clin Immunol 2021; Vol. 31(6): 461-470

doi: 10.18176/jiaci.0675

\begin{abstract}
The diagnosis of mast cell activation syndrome (MCAS) is defined by 3 criteria: (1) typical clinical signs and symptoms of acute, recurrent (episodic), and systemic mast cell activation (MCA); (2) increase in tryptase level to $>20 \%+2 \mathrm{ng} / \mathrm{mL}$ within $1-4$ hours after onset of the acute crisis; and (3) response of MCA symptoms to antimediator therapy. Classification of MCAS requires highly sensitive and specific methodological approaches for the assessment of clonal bone marrow mast cells at low frequencies. The Spanish Network on Mastocytosis score has been used successfully as a predictive model for selecting MCAS candidates for bone marrow studies based on a high probability of an underlying clonal mast cell disorder. In this article, we propose a diagnostic algorithm and focus on the practical evaluation and management of patients with suspected MCAS.
\end{abstract}

Key words: Anaphylaxis. Antimediator therapy. Mast cell activation syndrome. Mast cell mediator release-related symptoms. Tryptase.

\section{Resumen}

El diagnóstico de síndrome de activación mastocitaria (SAM) se basa en 3 criterios: 1) signos y síntomas específicos de activación mastocitaria aguda, recurrente y sistémica, 2) aumento de los valores de triptasa en un $20 \%+2 \mathrm{ng} / \mathrm{ml}$ sobre el valor basal de cada individuo en el periodo comprendido entre 1-4 horas desde el inicio del cuadro agudo, y 3) resolución de los síntomas con tratamiento antimediador. Para realizar el diagnóstico de SAM, es preciso emplear métodos diagnósticos altamente sensibles y específicos capaces de detectar bajas cantidades de mastocitos en la médula ósea. El modelo predictivo de la Red Española de Mastocitosis (REMA score) resulta útil para identificar a los pacientes con mayor probabilidad de padecer una patología mastocitaria clonal y que, por tanto, requieren que se realice un estudio de médula ósea en el proceso diagnóstico. En este artículo, proponemos un algoritmo diagnóstico para SAM y abordamos el manejo de estos pacientes desde un punto de vista práctico en la consulta alergológica.

Palabras clave: Anafilaxia. Síndrome de activación mastocitaria. Síntomas secundarios a la liberación de mediadores mastocitarios. Tratamiento antimediador. Triptasa. 


\section{Introduction}

Mast cells (MCs) are myeloid lineage-derived cells. They are present in connective tissue and play an important role as immunomodulatory and effector cells by releasing mediators that provoke clinically relevant reactions [1-3]. Correct diagnosis of mast cell activation syndrome (MCAS) is usually challenging for clinicians, since it is necessary to rule out conditions that mimic MCAS (eg, cardiovascular, endocrinologic, gastrointestinal, rheumatologic, and immunologic disorders) [4]. Symptoms of mast cell activation (MCA) are frequently nonspecific and can present in diverse physiologic and pathologic conditions. Thus, MCAS must be considered an unusual entity and may be diagnosed according to the following criteria [2,5,6]: (1) acute, recurrent (episodic), and systemic (involving at least 2 organ systems) signs and symptoms of MCA consistent with a diagnosis of anaphylaxis; (2) an increase in tryptase level from baseline to $>20 \%+2 \mathrm{ng} / \mathrm{mL}$ within 1-4 hours after onset of the reaction; and (3) clinical response to therapy with $\mathrm{MC}$-stabilizing agents that target MC mediator production and secretion or receptor binding. All 3 criteria must be fulfilled to establish the diagnosis of MCAS. Despite their great utility, they also present some limitations. Furthermore, since MCAS and its diagnostic criteria are primarily reported for adults, further studies are required for the evaluation of this entity in children [7].

\section{Clinical Signs and Symptoms of MCAS $[2,3,8]$}

MCA symptoms are secondary to the release of various vasoactive and proinflammatory $\mathrm{MC}$ mediators such as histamine, prostaglandins (PGs), leukotrienes (LTs), proteases, platelet-activating factor (PAF), growth factors, and cytokines. Different combinations of these mediators may be involved in MCA-related symptoms, which can present as acute episodes and/or chronic disease. Symptoms of MCA range from mild to severe and may even be life-threatening. Moreover, the trigger may be known (IgE- or non-IgE-mediated) or unknown. Thus, the clinical presentation of MCAS is very heterogeneous [9].

The clinical symptoms of diagnostic value in MCAS are grouped according to the following organ systems [3,8]:

1) Cardiovascular: hypotension, tachycardia, dizziness, and syncope.

2) Gastrointestinal: crampy abdominal pain, diarrhea, nausea, and vomiting.

3) Dermatologic: urticaria, angioedema, pruritus, and flushing.

4) Respiratory: wheezing, shortness of breath, and inspiratory stridor.

It should be emphasized that none of the above-mentioned symptoms are completely specific to MCAS. In fact, at least 2 organ systems need to be concurrently involved in an acute recurrent symptomatic crisis to fulfill the clinical criteria for MCAS (consistent with the working diagnosis of anaphylaxis). However, the clinical presentation of dizziness or syncope in a male triggered by a Hymenoptera sting is suspected of being associated with a clonal mast cell disorder (c-MCD) $[8,10]$. On the other hand, recent reports by specialized working groups on the topic $[2,3]$ recommend not considering for diagnostic purposes some of the nonspecific symptoms previously included (eg, nasal congestion, headache, neurologic symptoms, and fatigue) $[2,11,12]$ or other manifestations and conditions that lack precision for the diagnosis of MCAS or are not clearly related to MCA (eg, fibromyalgia-like pain, dermographism, tired appearance, chronically ill appearance, rashes of many sorts, prostatitis, various psychiatric and neurologic disorders, Ehlers-Danlos syndrome, and postural orthostatic tachycardia syndrome) [3].

Independently of the clinical picture, an appropriate evaluation of the symptoms or condition is mandatory. This should be performed according to evidence-based medical standards and by means of a complete differential diagnosis [4]. Therefore, misdiagnosis of MCAS or concomitant diseases would be avoided, even when the diagnosis of MCAS is well established.

\section{Monitoring of MC Mediators in the Clinical Diagnosis of MCAS}

The MC mediators used as biomarkers of MCA in various disorders (eg, allergen-triggered systemic anaphylaxis, systemic anaphylaxis associated with systemic mastocytosis [SM], aspirin-exacerbated respiratory disease) include tryptase (in serum or plasma), urine histamine metabolites (N-methylhistamine [N-MH] and N-methylimidazole acetic acid [MIAA]), and the urine metabolites of PGD2 and LTC4, ie, $11 \beta-P G F 2 \alpha$ and LTD4/LTE4, respectively $[3,6,13]$.

Histamine and tryptase are both produced and stored in tissue MCs and blood basophils. However, MCs contain $>100$-fold higher levels of tryptase than basophils [14], and immature (leukemic) basophils express relatively low amounts of tryptase [15]. Indeed, other cells can release histamine (eg, neutrophils, platelets, histamine-secreting carcinoid tumor cells), which is metabolized rapidly (halflife, 1-2 minutes), thus reducing the utility of this mediator as a clinical biomarker [13]. Nevertheless, some authors consider histamine-specific metabolites (N-MH and MIAA) to be appropriate biomarkers of systemic histamine release from MCs or basophils [13,16], although in one study [17], the measurement of 24-hour urine $\mathrm{N}-\mathrm{MH}$ was elevated in only 2 out of $25 \mathrm{MCAS}$ patients and showed little clinical utility for diagnosing MCAS.

While MCs are the major source of the previously mentioned mediators [13], other cell types also release such substances. PGD2 is produced mainly by $\mathrm{T}_{\mathrm{H}} 2$ lymphocytes, dendritic cells, megakaryocytes, and eosinophils; PGF2 is synthesized by the luteal endometrium, gestational tissues, human and primate granulosa cells, and hepatocytes; and LTC4 can be generated by basophils, eosinophils, monocytes, macrophages, and platelets $[3,13]$. Thus, of all these mediators, serum tryptase is considered the most accurate parameter for the evaluation of MCA [2] and is the biomarker used as a criterion for diagnosis of MCAS.

The commercially available ImmunoCAP Tryptase assay (ThermoFisher Scientific) detects total tryptase. Of 
note, $\alpha$-protryptase is released constitutively from MCs into plasma [18], while specific release of $\beta$-tryptase during anaphylaxis has been reported [19]. Increased tryptase levels in anaphylaxis induced by insect stings frequently correlate with the magnitude of hypotension during the episode. Furthermore, hypotension in anaphylaxis elicited by Hymenoptera venom is highly suspicious for underlying c-MCD [3,9,20-24].

A relationship has been reported between increased serum tryptase levels - either acute tryptase or acute/basal ratio (preferable) - detected during perioperative anaphylaxis, as has underlying IgE-mediated anaphylaxis [25-27]. On the other hand, when anaphylaxis is triggered by foods, the acute/basal ratio is more informative than peak tryptase determinations (usually in the normal range) [3,28-30].

Regarding postmortem serum tryptase, levels can be elevated in nonanaphylactic causes of death (eg, myocardial infarction, asphyxia, and trauma) [31,32]. A recent study established the postmortem tryptase reference value in nonanaphylactic death as $<23 \mu \mathrm{g} / \mathrm{L}$ [31]. In addition, tryptase levels can vary depending on perimortem and postmortem factors, including the sampling technique: it is recommended to take blood samples from a clamped femoral/external iliac vein [31].

Serum tryptase levels should be analyzed in the 1-4 hours after a suspicious MCA episode, and the result must be compared with the individual's previous serum baseline tryptase and/or the baseline levels must be determined at least 24-48 hours after the resolution of the clinical event (following the $>20 \%+2$ formula) $[6,33,34]$. Of note, the sensitivity of this tryptase algorithm decreases with decreasing clinical severity and with delayed blood extractions after the resolution of symptoms [2].

Tryptase can be analyzed in blood. However, measurement of other mediators (eg, urine) requires a period of 24 hours according to specific guidelines, including dietary restrictions (ie, histamine metabolites) [16,17]. Serum tryptase analysis immediately after an MC crisis may be difficult owing to logistic concerns (it is not routinely performed in the emergency department); therefore, in the authors' opinion, it is advisable to provide specific written instructions for the determination of serum tryptase to patients at risk of presenting an acute MCA crisis who require attention in the emergency department.

Although metabolites of PGD2 and cys-LTs (LTC4, LTD4, and LTE4) can be measured in random urine specimens [13] and serum samples [35], the commercial assays necessary to perform these analyses may not be available in some clinical settings. In addition, levels can be elevated in various reactive conditions (cell source might be ambiguous) and in mild mediator-related symptoms $[2,3,6]$. Thus, their contribution in the diagnosis of MCAS is not well defined, although some authors report their usefulness in guiding treatment that blocks the production of MC mediators [13].

Other parameters, such as diamino-oxidase and heparin, are not currently recommended as biomarkers of MCAS $[3,6]$.

Hereditary $\alpha$-tryptasemia $(\mathrm{H} \alpha \mathrm{T})$ is an autosomal dominant disorder characterized by increased copy numbers of the TPSAB 1 gene encoding $\alpha$-tryptase that is reported in $4 \%$ $8 \%$ of the general population [36-39]. A gene-dose effect has been reported between the number of $\alpha$-tryptase genes (assessed in a buccal swab [3] and peripheral blood or bone marrow [36]) and (1) basal serum tryptase levels and (2)

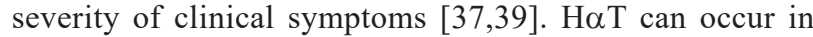
apparently healthy individuals with (slightly) elevated basal serum tryptase, although it is also associated with symptoms suggestive of autonomic dysfunction, flushing, pruritus, gastroesophageal reflux, joint hypermobility, arthralgia, irritable bowel syndrome, retained primary dentition, and immediate hypersensitivity reactions, among others. Interestingly, H $\alpha \mathrm{T}$ has also been described in c-MCD [39] and mastocytosis, more frequently among cases with Hymenoptera venom hypersensitivity reactions and severe cardiovascular

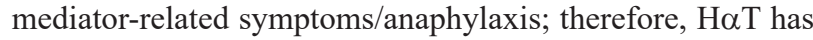
been proposed as an emerging biomarker in mastocytosis for determining the individual patient's risk of developing severe anaphylaxis [36]. Nevertheless, further studies are required to establish the role of $\mathrm{H} \alpha \mathrm{T}$ in MCAS.

\section{Therapeutic Options for MCA Symptoms}

Antimediator therapy aims to inhibit production, interfere with release, block specific receptors, and antagonize the effects of MC mediators. It is also used to treat and prevent acute and chronic MC mediator release-associated symptoms [40].

Given the highly heterogeneous clinical picture of MCAS (intensity, severity, trigger, unprovoked), the treatment of MCAS is on an individual basis using a combination of drugs, doses, and administration schedules (on-demand or continuous administration) in order to control symptoms and the underlying condition.

An on-demand schedule is used to control acute MCA episodes and, in the most severe cases, corresponds to acute treatment of systemic anaphylaxis [29]. It consists of the following: (1) removing the trigger when possible; (2) assessing the patient's circulation, airway, breathing, mental status, and skin; (3) placing the patient in the supine position (or in a position of comfort if there is respiratory distress and/or vomiting), with the legs raised; (4) calling for help and (self-) injection of intramuscular epinephrine in the mid-anterolateral thigh. If necessary, supplemental oxygen, intravenous fluids, cardiopulmonary resuscitation, and continuous noninvasive monitoring can be considered. In addition, intramuscular epinephrine is indicated in laryngeal angioedema and in severe bronchospasm, which can also be treated with inhaled rapidacting $\beta_{2}$ agonists [3].

Second-line medications, such as $\mathrm{H}_{1}$ and $\mathrm{H}_{2}$ antihistamines and corticosteroids, are also recommended in the treatment of anaphylaxis or acute MCA episodes [8,40]. Patients at risk for such events, as well as their relatives and care providers, should carry an epinephrine injector and be trained in the treatment of acute episodes.

As regards the prevention of presentation of MCA-related symptoms, it is important to avoid or adequately manage the general and specific triggers that may elicit release of MC mediators (eg, Hymenoptera venom, nonsteroidal antiinflammatory drugs, opioids, anesthetic procedures, iodinated contrast media) [3,40,41].

Furthermore, continuous antimediator therapy should be selected according to intensity and/or severity of MCA signs 
and symptoms. It is also important to evaluate possible MC mediator-related symptoms recorded between acute systemic MCA (anaphylactic) episodes.

Following previous recommendations, and based on the practice of mastocytosis experts [3,8,9,42-44], various drugs (alone or in specific combinations) are indicated, as follows: (1) oral sodium cromolyn (MC stabilizer); (2) scheduled or on-demand nonsedating $\mathrm{H}_{1}$ antihistamines (preferable) combined with a sedating antihistamine at night or on demand in selected highly symptomatic cases [44,45]; (3) scheduled $\mathrm{H}_{2}$ antihistamines; (4) scheduled leukotriene antagonists; and (5) corticosteroids for uncontrolled MC mediator-related symptoms. Table 1 shows a stepwise antimediator therapy approach for control of MC mediator-related symptoms.

Despite the lack of high-quality evidence based on welldesigned, double-blind, and placebo-controlled randomized trials (DBPCRT) to support recommendations regarding choice of $\mathrm{H}_{1}$ antihistamine or dosing [46], interesting data have been reported on this topic. Desloratadine and ketotifen have MCstabilizing properties $[47,48]$. In addition to its antimediator activity, loratadine inhibits spontaneous growth of neoplastic MCs in vitro [49]. PAF is a lipid-derived mediator involved in episodic hypotension and flushing in mastocytosis [50]. Rupatadine exerts an antagonistic effect against PAF receptor [51] and improves quality of life and MC-related symptoms (ie, itch, wheal, flare, flushing, tachycardia) in mastocytosis patients based on the results of a DBPCRT [50]. To a lesser extent, rupatadine and levocetirizine inhibit PAF degranulation induced in MCs in vitro [52].

$\mathrm{H}_{2}$ antihistamines are used specifically for treating gastric hypersecretion and peptic ulcer-related symptoms in patients with mastocytosis. They can also enhance the effect of $\mathrm{H}_{1}$

Table 1. Stepwise Antimediator Therapy for MC Mediator-Related Symptoms in MCAS $[3,8,40,42,43]$

\begin{tabular}{|c|c|c|}
\hline Symptoms & Therapy for chronic/recurrent symptoms & Therapy for acute episodes \\
\hline $\begin{array}{l}\text { Pruritus, urticaria, } \\
\text { and/or angioedema }\end{array}$ & $\begin{array}{l}\text { Nonsedating } \mathrm{H}_{1} \text {, up to } 4 \text {-fold doses } \\
+ \text { Topical cromolyn if skin lesions or pruritus } \\
\text { are restricted to small areas } \\
+ \text { Oral cromolyn } \\
+ \text { Omalizumab if uncontrolled CSU } \\
\pm \text { Sedating } \mathrm{H}_{1} \text { if uncontrolled episodes } \\
\pm \text { Systemic corticosteroids }^{\mathrm{a}}\end{array}$ & $\begin{array}{l}\text { Nonsedating } \mathrm{H}_{1} \\
+ \text { Topical cromolyn if skin lesions or pruritus } \\
\text { are restricted to small areas } \\
\pm \text { Sedating } \mathrm{H}_{1} \\
\pm \text { Systemic corticosteroids } \\
+ \text { Epinephrine if acute laryngeal angioedema }\end{array}$ \\
\hline Flushing & $\begin{array}{l}\text { Oral cromolyn }+ \text { nonsedating } \mathrm{H}_{1} \\
+\mathrm{H}_{2} \\
\pm \text { ASA if previous tolerance is demonstrated } \\
\pm \text { Sedating } \mathrm{H}_{1} \\
\pm \text { LT antagonists }\end{array}$ & $\begin{array}{l}\text { Nonsedating } \mathrm{H}_{1} \\
\pm \text { Sedating } \mathrm{H}_{1} \\
\pm \text { Systemic corticosteroids }\end{array}$ \\
\hline $\begin{array}{l}\text { Abdominal cramping } \\
\text { and/or diarrhea }\end{array}$ & $\begin{array}{l}\text { Oral cromolyn } \\
+{\mathrm{Nonsedating} \mathrm{H}_{1}} \\
\pm \mathrm{H}_{2} \\
\pm \text { Oral budesonide cycles } \\
\pm \mathrm{LT} \text { antagonists } \\
\pm \text { COX2-I if previous tolerance is demonstrated } \\
\pm \text { Low-dose systemic corticosteroid cycles }\end{array}$ & $\begin{array}{l}\text { Nonsedating } \mathrm{H}_{1} \\
\pm \text { Sedating } \mathrm{H}_{1} \\
\pm \text { Oral budesonide } \\
\pm \text { Antispasmodic drugs if acute episodes of pain } \\
\pm \text { Antidiarrheal drugs; if acute, severe, } \\
\text { and uncontrolled episodes of diarrhea } \\
\pm \text { Low-dose systemic corticosteroids }\end{array}$ \\
\hline Peptic symptoms & Oral cromolyn $+\mathrm{H}_{2}+\mathrm{PPI}$ & $\mathrm{H}_{2}+\mathrm{PPI}$ \\
\hline Anaphylaxis & $\begin{array}{l}\text { Oral cromolyn } \\
+ \text { VIT, if hymenoptera venom allergy } \\
+ \text { Nonsedating } \mathrm{H}_{1}+\mathrm{H}_{2} \text {, if idiopathic, } \\
\text { stress-induced, or uncontrolled anaphylaxis } \\
+ \text { Anxiolytics or antidepressants if } \\
\text { stress-induced anaphylaxis } \\
\pm \text { Sedating } \mathrm{H}_{1} \text { if stress-induced anaphylaxis } \\
+ \text { Omalizumab, if uncontrolled anaphylaxis } \\
\text { or bad tolerance to VIT }_{ \pm \text {IFN }^{\mathrm{a}}} \\
\pm \mathrm{TKI}^{\mathrm{a}}\end{array}$ & $\begin{array}{l}\text { Epinephrine } \\
\pm \text { Nonsedating or sedating } \mathrm{H}_{1} \pm \text { Systemic } \\
\text { corticosteroids } \\
\pm \mathrm{H}_{2} \\
+ \text { Inhaled short } \beta_{2} \text { agonist if bronchospasm } \\
\pm \text { Fluids } \\
\pm \text { Vasoactive drugs }\end{array}$ \\
\hline
\end{tabular}

Abbreviations: ASA, acetylsalicylic acid; COX2-I, cyclooxygenase 2 inhibitor; CSU, chronic spontaneous urticaria; $\mathrm{H}_{1}, \mathrm{H}_{1}$ antihistamine; $\mathrm{H}_{2}, \mathrm{H}_{2}$ antihistamine; LT, leukotriene; MC, mast cells, MCAS, mast cell activation syndrome; PPI, proton pump inhibitor; TKI, tyrosine-kinase inhibitor; VIT, venom immunotherapy.

aln selected unresponsive cases.

bEvaluate known tolerance if an opioid drug is prescribed.

'Avoidance of the specific trigger in food or drug anaphylaxis.

dSome cases may not require combination with cromolyn. 
antihistamines and prove useful in patients with abdominal pain, diarrhea, and recurrent, severe episodes of $\mathrm{MC}$ mediator release [45,53-56].

The precise mechanism of action of the MC stabilizer sodium cromolyn remains unclear. However, it inhibits activation of MCs and release of mediators by MCs in vitro and in vivo, inhibits GTP-g-S-induced exocytosis of MCs, and modulates sensory nerve function [57,58]. Moreover, despite its limited systemic absorption [59], DBPCRTs have shown that oral sodium cromolyn is effective for controlling gastrointestinal symptoms such as abdominal pain, vomiting, and diarrhea, in addition to other clinical manifestations associated with the release of MC mediators, such as pruritus and flushing [54,60-64]. Based on its experience, the Spanish Network on Mastocytosis (REMA), recommends the use of oral disodium cromolyn as treatment for chronic/recurrent MCA symptoms such as flushing, abdominal cramping, diarrhea, and unprovoked anaphylaxis [8,44,53]. Standard doses of oral disodium cromolyn for the adult population are $600-800 \mathrm{mg} / \mathrm{d}$, although this could be increased to $1600 \mathrm{mg} / \mathrm{d}$ if necessary [44].

Acetylsalicylic acid might control flushing and hypotension in selected cases with known tolerance to the drug and elevated urinary $11 \beta-\mathrm{PGF}_{2 \alpha}$ [3]. Celecoxib could be considered an option for intractable diarrhea in mastocytosis patients [65]. Montelukast has been shown to improve respiratory, cutaneous, and gastrointestinal symptoms in this population [66-68].

Systemic corticosteroids, which must be limited for long-term use owing to adverse effects, are recommended for refractory, acute, and/or severe MC mediator release-related symptoms. Corticosteroids can improve abdominal pain that is refractory to other options, and short cycles of low-doses prednisone $(0.3 \mathrm{mg} / \mathrm{kg} / \mathrm{d})$ or oral budesonide $(0.1 \mathrm{mg} / \mathrm{kg} / \mathrm{d})$ may be prescribed $[8,44,54,69]$.

Indeed, anti-IgE therapy with omalizumab has proven useful in cases with anaphylaxis that does not respond to conventional antimediator therapy $[3,8,9,40]$, as well as for reaching maintenance doses of venom immunotherapy (VIT) [70]. VIT is recommended in IgE-mediated Hymenoptera anaphylaxis requiring lifelong therapy $[71,72]$.

Currently, there is no consensus regarding recommendations about stepwise antimediator therapy or regarding the number of drugs or specific combinations to establish lack of response. The REMA defines the lack of response to antimediator therapy after failure to at least a combination of oral cromolyn, $\mathrm{H}_{1}$ and $\mathrm{H}_{2}$ antihistamines, antileukotrienes, and acetylsalicylic acid (or other cyclooxygenase inhibitors) [8].

A provisional diagnosis of "possibly MCAS" may be established in patients who present with acute, systemic, and recurrent MCA symptoms and a diagnostic increase in serum tryptase levels, in the absence of improvement with conventional antimediator therapy, which should be increased [2].

Bone mass loss, specifically osteoporosis, constitutes an important public and treatable health problem that should be evaluated in clonal MCs. It is a frequent finding in systemic mastocytosis (especially among patients without cutaneous involvement) $[10,73]$, secondary to local MC infiltration and disturbances in bone remodeling owing to $\mathrm{MC}$ mediators such as IL-6, histamine, and heparin [74,75]. Calcium, vitamin D supplements, and bisphosphonates are usually prescribed [76]. On the other hand, denosumab [77] and interferon $\alpha-2 b[78,79]$ might also be considered in patients with severe osteoporosis at risk of pathologic bone fractures who do not respond to conventional treatments.

\section{Classification of MCAS}

The current classification of MCAS establishes the following categories: (1) primary MCAS, where KIT-mutated, clonal (CD25+) MCs are detected (with or without an underlying diagnosis of mastocytosis); (2) secondary MCAS, in which usually an IgE-dependent allergy, another hypersensitivity reaction, or another immunologic disease that can evoke MCA is detected; and (3) idiopathic MCAS, with no detection of KITmutated MCs, other inflammatory disorders that may explain MCA, or a trigger for a hypersensitivity reaction [2].

According to the REMA experience, around 5\% of patients presenting with anaphylaxis in the absence of the typical skin lesions for mastocytosis may have an underlying clonal MCAS (c-MCAS) [80]. When the diagnostic criteria of MCAS are fulfilled, the evaluation of the typical D816V KIT mutation (or other gain-of-function KIT mutations) [81] should be considered. Immunophenotyping of bone marrow MCs is usually necessary to confirm or rule out a primary (clonal) MCAS. Some REMA data suggest greater utility for detection of the D816V KIT mutation, as assessed by allele-specific oligonucleotide quantitative polymerase chain reaction (ASO-qPCR) in fluorescence-activated cell sorting (FACS) of purified bone marrow MCs rather than in peripheral blood or unfractionated bone marrow samples [8]. If there is no evidence of clonality (CD25- bone marrow MCs and no KIT mutations), a nonclonal MCAS (nc-MCAS) should be considered, although the term nonclonal is based on the absence of currently detectable clonality [40].

Furthermore, whether clonal or not, co-occurrence of allergy or other underlying conditions according to the clinical features should be evaluated (Table 2) $[8,9,40]$. Thus, patients with an underlying c-MCD who experience IgEmediated anaphylaxis after Hymenoptera sting could be more specifically categorized $[8,10,40,82]$.

It is noteworthy that MCAS patients with associated skin lesions are usually c-MCD (either cutaneous mastocytosis or SM) [8]. Therefore, it has been recommended to use the diagnostic label 'SY' for symptoms (ie, indolent SM- $\mathrm{ISM}_{\mathrm{SY}^{-}}$) in mastocytosis cases, with any form of MCA requiring continuous antimediator therapy, even if the criteria for MCAS are not met $[2,33]$.

\section{Bone Marrow Aspirate and Biopsy: How and When?}

The bone marrow study does not quantify activation of MCs and does not have to be performed before starting antimediator therapy. It is well known that mastocytosis (or c-MCD) patients present remarkable clinical heterogeneity in the severity of MC mediator-related symptoms [9]. Furthermore, cytoreductive and/or targeted therapies should 
Table 2. Classification of Mast Cell Activation Syndromes [2,8]

\begin{tabular}{|c|c|c|c|}
\hline $\begin{array}{l}\text { Molecular } \\
\text { category }\end{array}$ & $\begin{array}{l}\text { Recognized } \\
\text { category }\end{array}$ & Diagnostic features of MCs & Underlying conditions \\
\hline \multirow[t]{3}{*}{ Clonal MCs } & \multirow[t]{3}{*}{ Primary } & $\begin{array}{l}\text { D816V KIT mutation and/or aberrant } \\
\text { expression of CD } 25^{+} \text {in MCs in BM } \\
\text { (WHO minor SM criteria) }\end{array}$ & c-MCAS (or MMAS) \\
\hline & & WHO criteria for SM are fulfilled & SM \\
\hline & & $\begin{array}{l}\text { Infiltration of skin by MCs, in the } \\
\text { absence of WHO criteria for } \mathrm{SM}^{\mathrm{b}}\end{array}$ & $\mathrm{CM}$ \\
\hline \multirow[t]{2}{*}{ Nonclonal MCs } & Secondary & $\begin{array}{l}\text { No KIT mutations detected } \\
\text { Expression of CD25- in MCs in BM }\end{array}$ & $\begin{array}{l}\text { IgE-mediated allergy, another hypersensitivity reaction, } \\
\text { or another immunologic (autoimmune, inflammatory) } \\
\text { disease that causes MCA }\end{array}$ \\
\hline & Idiopathic & $\begin{array}{l}\text { No KIT mutations detected }{ }^{c} \\
\text { Expression of CD25- in MCs in BM }\end{array}$ & $\begin{array}{l}\text { Neither primary nor secondary conditions } \\
\text { are found }\end{array}$ \\
\hline
\end{tabular}

Abbreviations: BM, bone marrow; CM, cutaneous mastocytosis; c-MCAS, clonal mast cell activation syndrome; MC, mast cells; MCA, mast cell activation; MCAS, mast cell activation syndrome; MMAS, monoclonal mast cell activation syndrome; SM, systemic mastocytosis; WHO, World Health Organization.

aOther gain-of-function KIT mutations are described [3,81].

bSkin MC infiltrate is accepted to be clonal MC proliferation.

cPotential existence of unknown molecular defects cannot be ruled out. Adapted with permission from Elsevier [8].

not be started in the absence of a complete bone marrow study, including mutated KIT status [3,9,40].

The evaluation of patients with suspected or confirmed MCAS should include a clinical, physical, and allergological work-up, together with a routine peripheral blood count and differential, routine biochemistry, and serum baseline tryptase (sBT). In addition, the bone marrow study is mandatory for the classification of MCAS (Table 2), and for diagnosis of underlying c-MCD in the absence of the typical skin lesions of mastocytosis (c-MCAS or SM) [9,40]. A relatively low MC burden in c-MCAS and indolent systemic mastocytosis without skin lesions of mastocytosis (ISMs-) has also been reported $[9,40,73]$. Highly sensitive and specific methodological approaches for the study of bone marrow MCs are required, including detailed cytological analysis of bone marrow smears, histology, immunochemistry, and flow cytometry-based immunophenotyping using specific gating strategies for detecting MCs present at low frequencies. Indeed, ASO-qPCR with unfractionated bone marrow and FACS with purified bone marrow are the techniques to be applied for detection of KIT mutations [81]. If the latter fails, the mutation could also be explored using peptide nucleic acid-mediated PCR clamping in FACS-purified bone marrow MCs. Finally, another useful option is sequencing of the whole KIT gene [8]. These complete methods are usually only available in high-efficiency reference centers for the diagnosis of c-MCD [83].

Some predictive models, such as the REMA score $[73,84,85]$ or the National Institutes of Health clinical activity score (including allele-specific PCR the KIT D816V mutation in peripheral blood) [86], have proven to be useful for selecting MCAS candidates for bone marrow studies based on a high probability of underlying c-MCD. The REMA score (Table 3) is based on sex, symptoms and signs observed during the acute episodes, and sBT levels. Below, we provide 2 brief examples of how to use the REMA score to evaluate systemic acute episodes in adult patients in the absence of skin lesions of mastocytosis (in some cases, patients can experience various episodes with different MCA-related symptoms each time): (1) In the case of a 35-year-old man who presented with dizziness and loss of consciousness after a wasp sting, the allergology work-up showed sensitization to Polistes dominula venom and an sBT of $10 \mathrm{ng} / \mathrm{mL}$. The REMA score was 4: male $(+1)$, no urticaria, no pruritus and no angioedema $(+1)$, syncope $(+3)$, and $\mathrm{sBT}<15 \mathrm{ng} / \mathrm{mL}(-1)$. (2) A 35-year-old man who presented with generalized urticaria, throat swelling, bronchospasm, abdominal cramping, diarrhea with no identified trigger after a thorough allergology work-up, and an sBT of $22 \mathrm{ng} / \mathrm{mL}$; the REMA score was -1 : male $(+1)$, urticaria and angioedema $(-2)$, and sBT not applicable.

Table 3. REMA Score

\begin{tabular}{llc} 
& Variable & Score $^{\mathrm{a}}$ \\
\hline Sex & Male & +1 \\
& Female & -1 \\
Clinical symptoms & No urticaria, no pruritus & \\
& and no angioedema & +1 \\
& Urticaria, pruritus & \\
& and/or angioedema & -2 \\
& Presyncope or syncope & +3 \\
sBT & $<15 \mathrm{ng} / \mathrm{mL}$ & -1 \\
& $>25 \mathrm{ng} / \mathrm{mL}$ & +2 \\
\hline
\end{tabular}

Abbreviations: MCAS, mast cell activation syndrome; REMA, Spanish Network on Mastocytosis; sBT, serum basal tryptase. Score $<2$ : low probability of clonal MCAS.

Score $\geq 2$ : high probability of clonal MCAS.

Sensitivity, 0.92; positive predictive value, 0.89 ; specificity, 0.81 ; negative predictive value, 0.87 .

Reproduced with permission from Elsevier and Karger $[73,84]$. 
The Figure proposes an algorithm for the diagnosis of MCAS. A REMA score $\geq 2$ is highly specific and sensitive for ISMs- or c-MCAS, and a bone marrow study is indicated. On the other hand, a REMA score $<2$ usually indicates nonclonal disease in this situation. If sBT levels are $<25-30 \mathrm{ng} / \mathrm{mL}$, then the KIT D816V mutation should be identified in peripheral

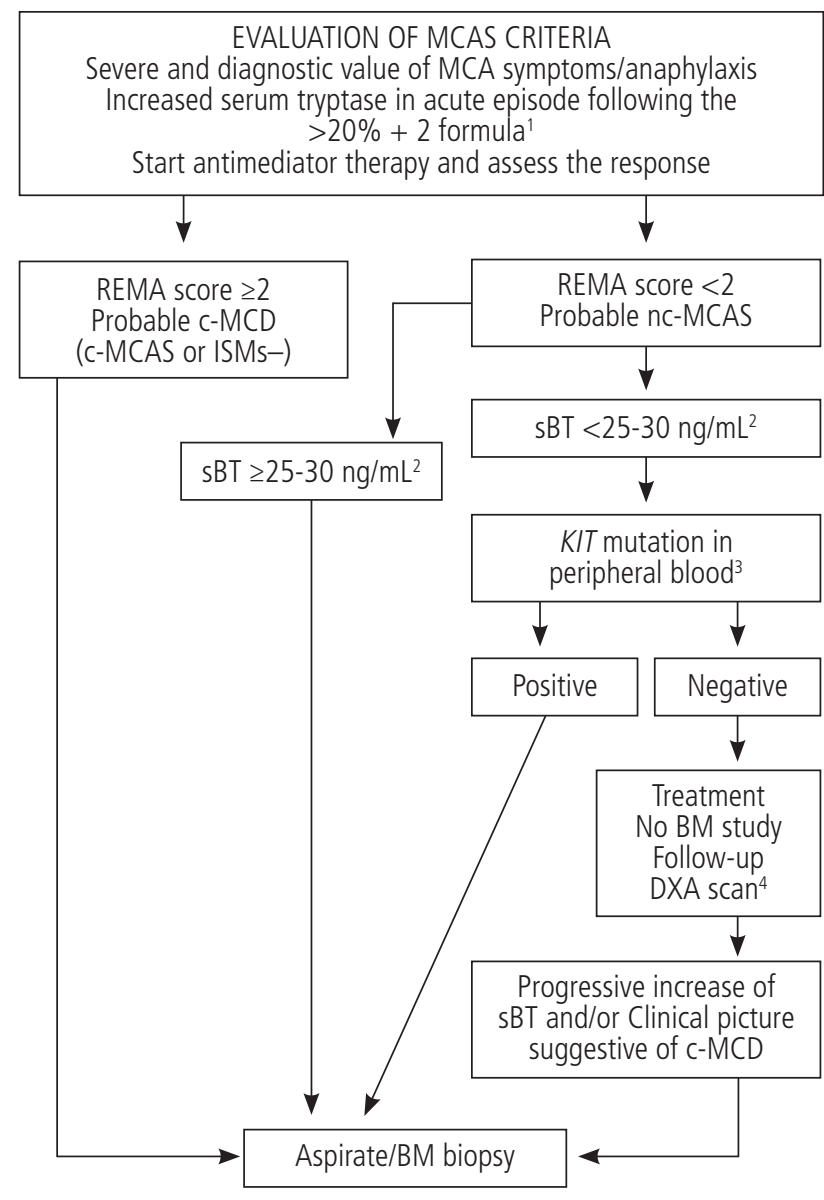

Figure 1. Proposed SEAIC algorithm for the diagnosis, management, and follow-up of MCAS patients based on REMA, ECNM, and AAAAI recommendations $[3,40,85]$. Highly sensitive diagnostic approaches are mandatory for detection of a low burden of pathological (clonal) bone marrow MCs, as could be expected in cases with a REMA score $\geq 2$ and low SBT levels. 1. Elevation of other validated MC mediators could be considered for evaluation. 2. sBT values are based on previous algorithms [85]. 3. Detection of the KITD816V mutation by ASOqPCR in peripheral blood; negative results related to a low allelic mutation burden should be considered $[87,88]$. 4. Bone mass loss is a frequent finding in SM, secondary to the release of MC mediators [40].

Evaluation of $\mathrm{H} \alpha \mathrm{T}$ could be considered in cases with elevated sBT and/or cardiovascular/anaphylaxis MC mediator-related symptoms.

AAAAI indicates American Academy of Allergy Asthma and Immunology; ASOqPCR, allele-specific oligonucleotide-quantitative polymerase chain reaction; $B M$, bone marrow; $C-M C A S$, clonal mast cell activation syndrome; C-MCD, clonal mast cell disorder; DXA, dual-energy x-ray absorptiometry; ECNM, European Competence Network on Mastocytosis; $\mathrm{H \alpha T}$, hereditary alpha tryptasemia; ISMs-, indolent systemic mastocytosis without skin lesion; MCA, mast cell activation; MCAS, mast cell activation syndrome; $M C$, mast cells; nc-MCAS, nonclonal mast cell activation syndrome; REMA, Spanish Network on Mastocytosis; sBT, serum basal tryptase; SEAIC Sociedad Española de Alergología e Inmunología Clínica; SM, systemic mastocytosis; VIT, venom immunotherapy. blood using ASOqPCR, and, if positive, a bone marrow study would be also indicated. Finally, the European Competence Network on Mastocytosis recommends performing a bone marrow study in cases with $\mathrm{sBT} \geq 25-30 \mathrm{ng} / \mathrm{mL}$. In these cases, $\mathrm{SM}$ and other clonal bone marrow diseases (eg, myeloproliferative neoplasm, myelodysplastic syndrome, or myeloid leukemia), renal failure, and genetic syndromes (eg, $\mathrm{H} \alpha \mathrm{T})$ should also be evaluated [85].

\section{Conclusions}

This article provides recommendations on the diagnosis and management of MCAS according to the most recent studies and consensus guidelines. Diagnosis of MCAS is based on 2 clinical criteria and 1 analytical criterion (blood sample) that can be applied as part of clinical routine. The subsequent classification based on the presence of clonal or nonclonal bone marrow MCs is often only available in specialized centers. In addition, other underlying conditions (eg, allergy) should be evaluated according to the clinical picture in each case. Patients with MCAS are usually cared for by multidisciplinary teams owing to the marked heterogeneity in clinical presentation and the methodological approaches required for management and classification. Further studies and advances are necessary to determine the frequency of MCAS in adults and children and thus specify and standardize clinical recommendations on stepwise antimediator therapy. It is also essential to address other areas, such as defining the criteria for characterizing the lack of response to antimediator therapy, improving the measurement and monitoring of MC mediators other than tryptase, understanding the relevance of increased copy numbers of the TPSAB 1 gene in MCAS, improving the efficiency in the detection of the KIT mutation in peripheral blood, and better characterizing nonclonal MCAS.

\section{Funding}

The authors declare that no funding was received for the present review.

\section{Conflicts of Interest}

Dr Perez-Gordo reports grants from Sociedad Española de Alergia e Inmunología Clínica outside the submitted work.

Dr Mariona Pascal Capdevila reports a grant from Sociedad Española de Alergia e Inmunología Clínica outside the submitted work.

The remaining authors declare that they have no conflicts of interest.

\section{References}

1. Khokhar D, Akin C. Mast Cell Activation: When the Whole Is Greater than the Sum of Its Parts. Med Clin North Am. 2020 Jan;104(1):177-87.

2. Valent $P$, Akin $C$, Bonadonna $P$, Hartmann $K$, Brockow $K$, Niedoszytko $M$, et al. Proposed Diagnostic Algorithm for Patients with Suspected Mast Cell Activation Syndrome. J Allergy Clin Immunol Pract. 2019 Apr;7(4):1125-33. 
3. Weiler $C R$, Austen KF, Akin C, Barkoff MS, Bernstein JA, Bonadonna $P$, et al. AAAAl Mast Cell Disorders Committee Work Group Report: Mast cell activation syndrome (MCAS) diagnosis and management. J Allergy Clin Immunol. 2019 Oct; 144(4):883-96.

4. Valent P, Akin C. Doctor, I Think I Am Suffering from MCAS: Differential Diagnosis and Separating Facts from Fiction. J Allergy Clin Immunol Pract. 2019 Apr;7(4):1109-14.

5. Arock M, Sotlar K, Gotlib J, Sperr WR, Hartmann K, Schwartz LB, et al. New developments in the field of mastocytosis and mast cell activation syndromes: a summary of the Annual Meeting of the European Competence Network on Mastocytosis (ECNM) 2019. Leuk Lymphoma. 2019 Dec 26;1-9.

6. Valent P, Bonadonna P, Hartmann K, Broesby-Olsen S, Brockow $\mathrm{K}$, Butterfield $\mathrm{JH}$, et al. Why the $20 \%+2$ Tryptase Formula Is a Diagnostic Gold Standard for Severe Systemic Mast Cell Activation and Mast Cell Activation Syndrome. Int Arch Allergy Immunol. 2019;180(1):44-51.

7. Broesby-Olsen $S$, Carter M, Kjaer HF, Mortz CG, Moller MB, Kristensen TK, et al. Pediatric Expression of Mast Cell Activation Disorders. Immunol Allergy Clin North Am. 2018 Aug;38(3):365-77.

8. Gonzalez-de-Olano D, Matito A, Alvarez-Twose I. Mast cell activation syndromes and anaphylaxis: Multiple diseases part of the same spectrum. Ann Allergy Asthma Immunol. 2020 Feb;124(2):143-5.

9. Matito A, Alvarez-Twose I, Morgado JM, Sanchez-Munoz L, Orfao A, Escribano L. Anaphylaxis as a clinical manifestation of clonal mast cell disorders. Curr Allergy Asthma Rep. 2014 Aug;14(8):450.

10. Alvarez-Twose I, Zanotti R, Gonzalez-de-Olano D, Bonadonna $P$, Vega A, Matito A, et al. Nonaggressive systemic mastocytosis (SM) without skin lesions associated with insect-induced anaphylaxis shows unique features versus other indolent SM. J Allergy Clin Immunol. 2014;133:520-8.

11. Valent P. Mast cell activation syndromes: definition and classification. Allergy. 2013 Apr;68(4):417-24.

12. Akin C, Valent P, Metcalfe DD. Mast cell activation syndrome: Proposed diagnostic criteria. J Allergy Clin Immunol. 2010 Dec;126(6):1099-104.

13. Butterfield J, Weiler CR. The Utility of Measuring Urinary Metabolites of Mast Cell Mediators in Systemic Mastocytosis and Mast Cell Activation Syndrome. J Allergy Clin Immunol Pract. 2020 Mar 3;(20):10.

14. Castells M, Irani AM, Schwartz LB. Evaluation of human peripheral blood leukocytes for mast cell tryptase. J Immunol. 1987;138:2184-9.

15. Samorapoompichit $P$, Kiener HP, Schernthaner GH, Jordan JH, Agis $\mathrm{H}$, Wimazal $\mathrm{F}$, et al. Detection of tryptase in cytoplasmic granules of basophils in patients with chronic myeloid leukemia and other myeloid neoplasms. Blood. 2001 Oct 15;98(8):2580-3.

16. Van Doormaal JJ, van der Veer $E$, Van Voorst Vader $P C$, Kluin PM, Mulder AB, Van der Heide $S$, et al. Tryptase and histamine metabolites as diagnostic indicators of indolent systemic mastocytosis without skin lesions. Allergy. $2012 \mathrm{Mar}$ 22;67(5):683-90.

17. Ravi A, Butterfield J, Weiler CR. Mast cell activation syndrome: improved identification by combined determinations of serum tryptase and 24-hour urine 11 beta-prostaglandin2alpha. J Allergy Clin Immunol Pract. 2014 Nov;2(6):775-8.
18. Schwartz LB, Sakai K, Bradford TR, Ren S, Zweiman B, Worobec $A S$, et al. The alpha form of human tryptase is the predominant type present in blood at baseline in normal subjects and is elevated in those with systemic mastocytosis. J Clin Invest. 1995 Dec;96(6):2702-10

19. Schwartz LB, Yunginger JW, Miller J, Bokhari R, Dull D. Time course of appearance and disappearance of human mast cell tryptase in the circulation after anaphylaxis. J Clin Invest. 1989:83:1551-5.

20. Vazquez-Revuelta P, Gonzalez-de-Olano D. Prevalence of Clonal Mast Cell Disorders in Patients Presenting With Hymenoptera Venom Anaphylaxis Might Be Higher Than Expected. J Investig Allergol Clin Immunol. 2018 Jun;28(3):193-4

21. Alvarez-Twose I, Bonadonna P, Matito A, Zanotti R, Gonzalezde-Olano D, Sanchez-Munoz L, et al. Systemic mastocytosis as a risk factor for severe Hymenoptera sting-induced anaphylaxis. J Allergy Clin Immunol. 2013;131:614-5.

22. Van der Linden P-WG, Hack CE, Poortman J, Vivié-Kipp YC, Struyvenberg A, Van der Zwan JK. Insect-sting challenge in 138 patients: Relation between clinical severity of anaphylaxis and mast cell activation. J Allergy Clin Immunol. 1992;90:110-8.

23. Schwartz LB, Metcalfe DD, Miller JS, Earl H, Sullivan T. Tryptase levels as an indicator of mast-cell activation in systemic anaphylaxis and mastocytosis. N Engl J Med. 1987;316:1622-6.

24. Bonadonna P, Scaffidi L, Boni E. Tryptase values in anaphylaxis and insect allergy. Curr Opin Allergy Clin Immunol. 2019 Oct; 19(5):462-7.

25. Gastaminza G, Lafuente A, Goikoetxea MJ, D'Amelio CM, Bernad-Alonso A, Vega O, et al. Improvement of the Elevated Tryptase Criterion to Discriminate IgE- From Non-IgE-Mediated Allergic Reactions. Anesth Analg. 2018 Aug;127(2):414-9.

26. Krishna MT, York M, Chin T, Gnanakumaran G, Heslegrave J, Derbridge C, et al. Multi-centre retrospective analysis of anaphylaxis during general anaesthesia in the United Kingdom: aetiology and diagnostic performance of acute serum tryptase. Clin Exp Immunol. 2014 Nov; 178(2):399-404.

27. Misbah SA, Krishna MT. Peri-Operative Anaphylaxis An Investigational Challenge. Front Immunol 2019 May 29;10:1117. doi: 10.3389/fimmu.2019.01117. eCollection;\%2019.:1117.

28. Dua S, Dowey J, Foley L, Islam S, King Y, Ewan P, et al. Diagnostic Value of Tryptase in Food Allergic Reactions: A Prospective Study of 160 Adult Peanut Challenges. J Allergy Clin Immunol Pract. 2018 Sep;6(5):1692-8.

29. Simons FE, Ebisawa M, Sanchez-Borges M, Thong BY, Worm M, Tanno LK, et al. 2015 update of the evidence base: World Allergy Organization anaphylaxis guidelines. World Allergy Organ J. 2015 Oct 28;8(1):32-0080.

30. Wongkaewpothong P, Pacharn $P$, Sripramong $C$, Boonchoo S, Piboonpocanun S, Visitsunthorn $N$, et al. The utility of serum tryptase in the diagnosis of food-induced anaphylaxis. Allergy Asthma Immunol Res. 2014 Jul;6(4):304-9.

31. Garland J, Philcox W, McCarthy S, Mathew S, HensbyBennett S, Ondrushka B, et al. Postmortem Tryptase Level in 120 Consecutive Nonanaphylactic Deaths: Establishing a Reference Range as $<23 \mu \mathrm{g} / \mathrm{L}$. Am J Forensic Med Pathol. 2019 Dec;40(4):351-5.

32. Lean-Tooke A, Goulding M, Bundell C, White J, Hollingsworth P. Postmortem serum tryptase levels in anaphylactic and nonanaphylactic deaths. J Clin Pathol. 2014 Feb;67(2):134-8. 
33. Valent $P$, Akin C, Arock M, Brockow K, Butterfield JH, Carter MC, et al. Definitions, Criteria and Global Classification of Mast Cell Disorders with Special Reference to Mast Cell Activation Syndromes: A Consensus Proposal. Int Arch Allergy Immunol. 2012 Oct 27;157(3):215-25.

34. Schwartz LB. Diagnostic value of tryptase in anaphylaxis and mastocytosis. Immunol Allergy Clin North Am. 2006 Aug:26(3):451-63.

35. Nassiri M, Eckermann O, Babina M, Edenharter G, Worm M. Serum levels of 9alpha,11beta-PGF2 and cysteinyl leukotrienes are useful biomarkers of anaphylaxis. J Allergy Clin Immunol. 2016 Jan;137(1):312-4.

36. Greiner G, Sprinzl B, Górska A, Ratzinger F, Gurbisz M, Witzeneder $N$, et al. Hereditary alpha tryptasemia is a valid genetic biomarker for severe mediator-related symptoms in mastocytosis. Blood. 2021;137(2):238-47.

37. Lyons JJ, Yu X, Hughes JD, Le QT, Jamil A, Bai Y, et al. Elevated basal serum tryptase identifies a multisystem disorder associated with increased TPSAB 1 copy number. Nat Genet. 2016 Dec;48(12):1564-9.

38. Lyons JJ. Hereditary Alpha Tryptasemia: Genotyping and Associated Clinical Features. Immunol Allergy Clin North Am. 2018 Aug;38(3):483-95.

39. Sabato V, Chovanec J, Faber M, Milner JD, Ebo D, Lyons JJ. First Identification of an Inherited TPSAB 1 Quintuplication in a Patient with Clonal Mast Cell Disease. J Clin Immunol. 2018 May;38(4):457-9.

40. Gonzalez de Olano D, Matito A, Orfao A, Escribano L. Advances in the understanding and clinical management of mastocytosis and clonal mast cell activation syndromes. F1000Res 2016 Nov 14;5:2666.

41. Carter MC, Metcalfe DD, Matito A, Escribano L, Butterfield JH, Schwartz LB, et al. Adverse reactions to drugs and biologics in patients with clonal mast cell disorders: A Work Group Report of the Mast Cells Disorder Committee, American Academy of Allergy, Asthma \& Immunology. J Allergy Clin Immunol. 2019 Mar; 143(3):880-93.

42. Castells M, Butterfield J. Mast Cell Activation Syndrome and Mastocytosis: Initial Treatment Options and LongTerm Management. J Allergy Clin Immunol Pract. 2019 Apr;7(4):1097-106.

43. Azana JM, Torrelo A, Matito A. Update on Mastocytosis (Part 2): Categories, Prognosis, and Treatment. Actas Dermosifiliogr. 2016;107:15-22.

44. Gonzalez de Olano D, Alvarez-Twose I, Castells Guitart M, Ferrer Puga M, Escribano Mora L. Síndromes de activación mastocitaria. In: Dávila Gonzalez I, Jáuregui Presa I, Olaguibel Rivera J, Zubeldia Ortuño J, editors. Tratado de Alergología. SEAIC., 2 Ed ed Ergon; 2016.

45. Cardet JC, Akin C, Lee MJ. Mastocytosis: update on pharmacotherapy and future directions. Expert Opin Pharmacother. 2013 Oct; 14(15):2033-45.

46. Nurmatov UB, Rhatigan $E$, Simons FE, Sheikh A. H1antihistamines for primary mast cell activation syndromes: a systematic review. Allergy. 2015 Sep;70(9):1052-61.

47. Okayama Y, Church MK. Comparison of the modulatory effect of ketotifen, sodium cromoglycate, procaterol and salbutamol in human skin, lung and tonsil mast cells. Int Arch Allergy Immunol. 1992;97(3):216-25.
48. Weller K, Maurer M. Desloratadine Inhibits Human Skin Mast Cell Activation and Histamine Release. J Invest Dermatol. 2009 Nov; 129(11):2723-6.

49. Hadzijusufovic E, Peter B, Gleixner KV, Schuch K, Pickl WF, Thaiwong $T$, et al. H1-receptor antagonists terfenadine and loratadine inhibit spontaneous growth of neoplastic mast cells. Exp Hematol. 2010 Oct;38(10):896-907.

50. Siebenhaar F, Fortsch A, Krause K, Weller K, Metz M, Magerl $M$, et al. Rupatadine improves quality of life in mastocytosis: a randomized, double-blind, placebo-controlled trial. Allergy. $2013 \mathrm{Jul} ; 68(7): 949-52$.

51. Mullol J, Bousquet J, Bachert C, Canonica GW, GimenezArnau $A$, Kowalski $M L$, et al. Update on rupatadine in the management of allergic disorders. Allergy. 2015 Jan; 70 Suppl 100:1-24

52. Munoz-Cano $R$, insua-Enrich $E$, Torres-Atencio I, Martin M, Sanchez-Lopez J, Bartra J, et al. Effects of Rupatadine on Platelet- Activating Factor-Induced Human Mast Cell Degranulation Compared With Desloratadine and Levocetirizine (The MASPAF Study). J Investig Allergol Clin Immunol. 2017;27(3):161-8.

53. Alvarez-Twose I, Matito A, Sanchez-Munoz L, Morgado JM, Escribano L. Management of adult Mastocytosis. Expert Opin. 2014;2(4).

54. Escribano L, Akin C, Castells M, Schwartz LB. Current options in the treatment of mast cell mediator-related symptoms in mastocytosis. Inflamm Allergy Drug Targets. 2006 Jan;5(1):61-77.

55. Gasior-Chrzan B, Falk ES. Systemic mastocytosis treated with histamine $\mathrm{H} 1$ and $\mathrm{H} 2$ receptor antagonists. Dermatologica. 1992;184:149-52.

56. Hirschowitz BI, Groarke JF. Effect of cimetidine on gastric hypersecretion and diarrhea in systemic mastocytosis. Ann Intern Med. 1979 May;90(5):769-71.

57. Martin MW, O'Sullivan AJ, Gomperts BD. Inhibition by cromoglycate and some flavonoids of nucleoside diphosphate kinase and of exocytosis from permeabilized mast cells. Br J Pharmacol. 1995;115:1080-6.

58. Norris AA. Pharmacology of sodium cromoglycate. Clin Exp Allergy. 1996 Jun;26 Suppl 4:5-7.

59. Advenier C, Ruff F. [Cromoglycic acid (disodium cromoglycate) and inhibitors of mast cell degranulation]. Sem Hop. 1984 Feb 23:60(9):659-64.

60. Czarnetzki BM, Behrendt H. Urticaria pigmentosa: clinical picture and response to oral disodium cromoglycate. $\mathrm{Br} J$ Dermatol. 1981 Nov; 105(5):563-7.

61. Dolovich J, Punthakee ND, MacMillan AB, Osbaldeston GJ. Systemic mastocytosis: control of lifelong diarrhea by ingested disodium cromoglycate. Can Med Assoc J. 1974 Oct 5;111(7):684-5.

62. Edwards AM, Capkova S. Oral and topical sodium cromoglicate in the treatment of diffuse cutaneous mastocytosis in an infant. BMJ Case Rep. 2011 Jun 29;2011: bcr0220113910.

63. Horan RF, Sheffer AL, Austen KF. Cromolyn sodium in the management of systemic mastocytosis. J Allergy Clin Immunol. 1990 May;85(5):852-5.

64. Welch EA, Alper JC, Bogaars H, Farrell DS. Treatment of bullous mastocytosis with disodium cromoglycate. J Am Acad Dermatol. 1983;9(3):349-53.

65. Moreno-Borque R, Matito A, varez-Twose I, Morgado JM, Sanchez-Munoz L, Orfao A, et al. Response to celecoxib in a 
patient with indolent systemic mastocytosis presenting with intractable diarrhea. Ann Allergy Asthma Immunol. 2015 Nov; 115(5):456-7.

66. Sancho-Chust JN, Chiner E, Camarasa A, Llombart M. Recent-onset bronchial asthma as a manifestation of systemic mastocytosis. J Investig Allergol Clin Immunol. 2009;19(6):513-5.

67. Tolar J, Tope WD, Neglia JP. Leukotriene-receptor inhibition for the treatment of systemic mastocytosis. N Engl J Med. 2004 Feb 12;350(7):735-6.

68. Turner PJ, Kemp AS, Rogers M, Mehr S. Refractory symptoms successfully treated with leukotriene inhibition in a child with systemic mastocytosis. Pediatr Dermatol. 2012 Mar;29(2):222-3.

69. Matito A, Morgado JM, Alvarez-Twose I, Laura S, Pedreira CE, Jara-Acevedo $\mathrm{M}$, et al. Serum tryptase monitoring in indolent systemic mastocytosis: association with disease features and patient outcome. PLoS One. 2013 Oct 1:8:76116e.

70. Gonzalez-de-Olano D, Padial-Vilchez MA, Núñez-Acevedo $B$ de-Calzada-Bustingorri MP, de-Andrés-Martín A, Caldas C, et al. Usefulness of Omalizumab and Sting Challenge Test in Hymenoptera Venom Allergy and Mastocytosis. J Investig Allergol Clin Immunol. 2019;29(4):318-20.

71. Bonadonna P, Gonzalez de Olano D, Zanotti R, Riccio A, De Ferrari L, Lombardo $\mathrm{C}$, et al. Venom immunotherapy in patients with clonal mast cell disorders: Efficacy, safety, and practical considerations. J Allergy Clin Immunol: In Practice. Sep-Oct 2013;1(5):474-8.

72. Gonzalez de Olano D, Alvarez-Twose I, Vega A, Orfao A, Escribano L. Venom immunotherapy in patients with mastocytosis and hymenoptera venom anaphylaxis. Immunotherapy. 2011 May;3(5):637-51.

73. Alvarez-Twose I, Gonzalez de Olano D, Sanchez-Munoz L, Matito A, Esteban-Lopez MI, Vega A, et al. Clinical, biological and molecular characteristics of systemic mast cell disorders presenting with severe mediator-related symptoms. J Allergy Clin Immunol. 2010;125(6):1269-78.

74. Manolagas SC, Jilka RL. Bone marrow, cytokines, and bone remodeling. Emerging insights into the pathophysiology of osteoporosis. N Engl J Med. 1995 Feb 2;332(5):305-11.

75. Rabenhorst A, Christopeit B, Leja S, Gerbaulet A, Kleiner S, Forster $A$, et al. Serum levels of bone cytokines are increased in indolent systemic mastocytosis associated with osteopenia or osteoporosis. J Allergy Clin Immunol. 2013 Nov;132(5):12347.

76. Rossini M, Zanotti R, Viapiana O, Tripi G, Orsolini G, Idolazzi $L$, et al. Bone involvement and osteoporosis in mastocytosis. Immunol Allergy Clin North Am. 2014 May;34(2):383-96.

77. Orsolini G, Gavioli I, Tripi G, Viapiana O, Gatti D, Idolazzi $L$, et al. Denosumab for the Treatment of MastocytosisRelated Osteoporosis: A Case Series. Calcif Tissue Int. 2017 Jun;100(6):595-8

78. Lehmann T, Beyeler C, Lämmle B, Hunziker T, Vock P, Olah AJ, et al. Severe osteoporosis due to systemic mast cell disease: Successful treatment with interferon alpha-2b. Br J Rheumatol. 1996;35(9):898-900.

79. Weide R, Ehlenz K, Lorenz W, Walthers E, Klausmann M, Pflüger KH. Successful treatment of osteoporosis in systemic mastocytosis with interferon alpha-2b. Ann Hematol. 1996;72(1):41-3.
80. Gonzalez-de-Olano D, Esteban-Lopez MI, Alonso-Diaz-deDurana MD, Gonzalez-Mancebo E, Prieto-Garcia A, GandolfoCano $M$, et al. Frequency of clonal mast cell diseases among patients presenting with anaphylaxis: A prospective study in 178 patients from 5 tertiary centers in Spain. J Allergy Clin Immunol Pract. 2019 Nov;7(8):2924-6.

81. Sanchez-Munoz L, Henriques AF, varez-Twose I, Matito $A$. Bone Marrow Expression of Mast Cell Disorders. Immunol Allergy Clin North Am. 2018 Aug;38(3):379-95.

82. Bonadonna P, Perbellini O, Passalacqua G, Caruso B, Colaross $\mathrm{S}$, Dal FD, et al. Clonal mast cell disorders in patients with systemic reactions to Hymenoptera stings and increased serum tryptase levels. J Allergy Clin Immunol. 2009 Mar;123(3):6806.

83. Sanchez-Munoz L, Morgado JM, Álvarez-Twose I, Matito A, Garcia-Montero AC, Teodosio C, et al. Diagnosis and classification of mastocytosis in non-specialized versus reference centres: a Spanish Network on Mastocytosis (REMA) study on 122 patients. Br J Haematol. 2015 Oct 12;10.

84. Alvarez-Twose I, Gonzalez-de-Olano D, Sanchez-Munoz L, Matito A, Jara-Acevedo M, Teodosio C, et al. Validation of the REMA Score for Predicting Mast Cell Clonality and Systemic Mastocytosis in Patients with Systemic Mast Cell Activation Symptoms. Int Arch Allergy Immunol. 2011 Oct 28;157(3):275-80.

85. Valent $\mathrm{P}$, Escribano L, Broesby-Olsen S, Hartmann K, Grattan C, Brockow K, et al. Proposed diagnostic algorithm for patients with suspected mastocytosis: a proposal of the European Competence Network on Mastocytosis. Allergy. 2014:69:1267-74

86. Carter MC, Desai A, Komarow HD, Bai Y, Clayton ST, Clark AS, et al. A distinct biomolecular profile identifies monoclonal mast cell disorders in patients with idiopathic anaphylaxis. J Allergy Clin Immunol. 2018 Jan;141(1):180-8.

87. Jara-Acevedo M, Teodosio C, Sanchez-Munoz L, varez-Twose I, Mayado A, Caldas C, et al. Detection of the KIT D816V mutation in peripheral blood of systemic mastocytosis: diagnostic implications. Mod Pathol. 2015 Aug;28(8):113849

88. Carter MC, Bai Y, Ruiz-Esteves KN, Scott LM, Cantave D, Bolan $\mathrm{H}$, et al. Detection of KIT D816V in peripheral blood of children with manifestations of cutaneous mastocytosis suggests systemic disease. Br J Haematol. 2018 Dec;183(5):775-82.

Manuscript received September 7, 2020; accepted for publication January 28, 2021.

\section{- Almudena Matito}

Instituto de Estudios de Mastocitosis de Castilla La Mancha Hospital Virgen de Valle

Carretera de Cobisa, $\mathrm{s} / \mathrm{n}$

45071 Toledo, Spain

E-mail: almudenamatito@gmail.com 